\title{
Biodiversity of the Pantanal: response to seasonal flooding regime and to environmental degradation
}

\author{
Alho, CJR.* \\ Pós-graduação em Meio Ambiente e Desenvolvimento Regional, \\ Universidade Para o Desenvolvimento do Estado e da Região do Pantanal - UNIDERP, \\ Rua Ceará, 333, CEP 79003-010, Campo Grande, MS, Brazil \\ *e-mail: alho@unb.br
}

Received December 27, 2007 - Accepted December 27, 2007 - Distributed November 30, 2008

(With 1 gure)

\begin{abstract}
Seasonal flooding is the most important ecological phenomenon in the Pantanal. Every year many parts of the biome change from terrestrial into aquatic habitats and vice-versa. The degree of inundation creates a range of major habitats. Flooding occupies about $80 \%$ of the whole Pantanal. In contrast, during the dry season, most of the flooded areas stay dry, when the water returns to the river beds or evaporates. The Pantanal is a large continental savanna wetland $\left(147,574 \mathrm{~km}^{2}\right.$ in Brazil), touching Bolivia to the north and Paraguay to the south. The maze of fluctuating water levels, nutrients, and biota forms a dynamic ecosystem. The vegetation comprises 1,863 phanerogam plant species listed for the floodplain and 3,400 for the whole basin and 250 species of aquatic plants. The complex vegetation cover and seasonal productivity support a diverse and abundant fauna within the floodplain: 263 species of sh, 41 of amphibians, 113 of reptiles (177 for the basin), 463 of birds and 132 mammal species. Many endangered species occur, including jaguar (Panthera onca Linnaeus, 1758). Waterfowl are exceptionally abundant during the dry season. Analysis of the root causes of the threats to biodiversity indicated that deforestation (17\% of the Pantanal and 63\% of the surrounding uplands) with modi cation and loss of natural habitats due to cattle ranching, unsustainable agriculture, mining, environmental contamination (including mercury, pesticides, urban sewage), non organized tourism, re, disturbances at the upstream region modifying hydrological flow, erosion, weak implementation and enforcement of legislation are the major issues to face conservation action and sustainable use. Under an evolutionary focus, local biodiversity seems to be well adapted to seasonal shrinking and expansion of natural habitats due to flooding. However, the conversion of natural vegetation due to human occupation is a real threat to biodiversity.
\end{abstract}

Keywords: biodiversity, conservation, fauna, flora, Pantanal.

\section{Biodiversidade do Pantanal: resposta ao regime sazonal de enchente e à degradação ambiental}

\begin{abstract}
Resumo
Inundação sazonal é o fenômeno ecológico mais importante do Pantanal. A cada ano, grandes regiões do bioma mudam de hábitats aquáticos para terrestres e vice-versa. As cheias ocupam cerca de $80 \%$ do Pantanal. Em contraste, durante a estiagem, grande parte da área inundada seca, quando a água retorna para o leito dos rios ou evapora. $\mathrm{O}$ Pantanal é uma grande área continental inundável (147.574 $\mathrm{km}^{2}$ no Brasil), com partes menores tocando a Bolívia ao norte e o Paraguai ao sul. O complexo de níveis de inundação, nutrientes e biota forma um sistema dinâmico. A vegetação compreende 1.863 espécies de plantas fanerógamas que ocorrem no Pantanal e 3.400 que se distribuem na Bacia do Alto Paraguai, além de 250 espécies de plantas aquáticas. Essa complexa cobertura vegetal e a produtividade sazonal dão suporte ecológico para uma fauna diversa e abundante do Pantanal: 263 espécies de peixes, 41 de anfíbios, 113 de répteis (177 Para a Bacia), 463 de aves e 132 de mamíferos. Ocorrem muitas espécies ameaçadas de extinção como a onça Panthera onca Linnaeus, 1758. Aves aquáticas são excepcionalmente abundantes na estação seca. A análise das causas-raízes das ameaças ambientais à biodiversidade indica que $17 \%$ do Pantanal e $63 \%$ do Planalto do seu entorno sofreram perdas e modi cações de hábitats naturais devido à pecuária e agricultura não sustentáveis, mineração, contaminação ambiental (incluindo contaminação por mercúrio, pesticidas e esgoto urbano), turismo não-sustentável, fogo, mudanças no fluxo das nascentes de rios, erosão, ação de conservação de ciente, com ine ciente implementação da legislação ambiental. Sob o enfoque evolucionário, a biodiversidade do Pantanal parece estar bem adaptada à expansão e ao encolhimento sazonal dos hábitats naturais devido à inundação. Contudo, a perda
\end{abstract}


e alteração de hábitats devido à conversão da vegetação natural pela ocupação humana, constituem uma ameaça real, com prejuízo para a biodiversidade.

Palavras-chave: biodiversidade, conservação, fauna, flora, Pantanal.

\section{Ecological Processes Favoring Biodiversity: Flooding Regime and Seasonal Productivity}

Large and environmentally heterogeneous wetlands like the Pantanal $\left(147,574 \mathrm{~km}^{2}\right.$ - latitude $15^{\circ} 30^{\prime}-22^{\circ} 30^{\prime} \mathrm{S}$ and longitude $54^{\circ} 45^{\prime}-58^{\circ} 30^{\prime} \mathrm{W}$ ) play an important role in biological diversity, because of the diversity of natural habitats offering opportunities for feeding and reproductive niches, in addition to many essential ecosystem services including carbon storage, flood control, sh production, and aquifer recharge (Alho, 2005; Alho and Gonçalves, 2005; Alho et al., 1988a; Keddy and Fraser, 2005). Other functions have more complex relationships since species richness or biodiversity generally increases with area, under an evolutionary process. On the other hand, habitat insularization of a biota within a small area contributes to a reduction in the number of species, according to the theory of island biogeography (Shafer, 1990). This is a well known phenomenon in Ecology named species-area relationship. (Figure 1).

The most striking aspect of the Pantanal is its curious combination of mesic and xeric vegetation growing side by side due to seasonal flooding. The relationship among slope-soil/water/vegetation cover/fauna, is signi cant in differentiating the Pantanal plains, with an average altitude of 80 to $150 \mathrm{~m}$, from their surrounding plateaus (Planalto) with altitudes varying from 200 to $1,200 \mathrm{~m}$. The Pantanal is located in a climatic dry area.

The Pantanal is a sedimentary basin, a mosaic of alluvial fans of Pleistocene (11,000 to 1.8 million years) origin, periodically flooded, surrounded by highlands. The relief of the Upper Paraguay Basin is marked with contrasts between the low and flat floodplain (Pantanal) and the surrounding non-flooded lands of plateaus and depressions (Planalto).

The present landscape arrangement and natural ecosystems are the result of three factors: 1) geological changes occurring since the Quaternary, which probably influenced the drainage patterns of the region; 2) the pronounced differences in annual cycles of wet and dry seasons plus exceptional periods of long flooding or droughts causing retraction or expansion of the Pantanal, thus, a phenomena related to greater or lesser primary productivity and ecological succession and 3) areas related to human intervention such as pastures, arti cial ponds or introduced trees near the ranch houses.

The rainy season, with most rain falling between November and March, but with variations between the northern and the southern regions, varies annually from 1,200 to $1,300 \mathrm{~mm}$ across the region and in some years can reach 2,000 $\mathrm{mm}$. Rainfall is more intensive in the northern uplands than in the south. From May to October the land dries out and grasslands and scattered pools (locally named "baías") appear. The reasons for this mixture are the topography and the seasonal climate. Hence, the patches of forest experience severe drought during the six-month dry season. The mixture of permanent and temporary flooded habitats, and gallery forests or patches of woodland, contributes to the richness of the vegetation and productivity of the system, which, in turn, supports the exuberant abundance of fauna.

The major rivers feeding the Pantanal are (from north to south): Paraguay, Bento Gomes, Cuiabá, São Lourenço-Itiquira, Taquari, Negro, Aquidauana-Miranda, Nabileque and Apa. These tributaries of the Paraguay are slow moving when they meet the flatland and have coves with adjacent flood land. They periodically overflow their banks. The maze of fluctuating water levels, nutrients, and wildlife forms a dynamic ecosystem. The flooding occupies about $80 \%$ of the whole Pantanal. In contrast, during the dry season, most of the flooded areas stay dry, when the water returns to the river beds or evaporates.

Annual rainfall in the highlands is generally above $1,200 \mathrm{~mm}$, which produces a rapid response in the drainage basin. Water nds reduced runoff on the plains, flooding the region. Depressions retain water volume, forming small temporary lakes and ponds (locally known as "baías") or flooding the permanent ones. During low water times the retained water volume does not return to the riverbed to be drained, but remains where it is and evaporates or in ltrates the soil. The rainfall level on the plains (Pantanal) is from 800 to $1,200 \mathrm{~mm}$ and potential evaporation is 1,300 to $1,600 \mathrm{~mm}$, and so the hydric balance is negative. Evaporation of water from the land is greater than the volume of water received through precipitation. The retention of water on the plains reaches 30 to $60 \%$, transforming the Pantanal into a wetland. In the north, flooding occurs from March to April and from July to August in the south.

In the floodplain (Pantanal) the topographical gradients are weak, with the slope ranging from 0.3 to $0.5 \mathrm{~m} . \mathrm{km}^{-1}$ east-west and 0.03 to $0.15 \mathrm{~m} . \mathrm{km}^{-1}$ north-south (Franco and Pinheiro, 1982). The river slope in the highlands (plateaus surrounding the Pantanal) is about $0.6 \mathrm{~m} \cdot \mathrm{km}^{-1}$, while on the plain it is 0.1 to $0.3 \mathrm{~m} \cdot \mathrm{km}^{-1}$. The slow flow of the rivers when they reach the floodplain results in decreased current velocity and loss of most of the suspended sediment. Dissolved oxygen $\left(\mathrm{O}_{2}\right)$ concentrations drop drastically, followed by accumulation of dissolved carbon dioxide $\left(\mathrm{CO}_{2}\right)$ and decreased $\mathrm{pH}$ (Hamilton et al., 1995).

Seasonal flooding and nutrients - Water chemistry, frequency and degree of flooding, soil types, and other 


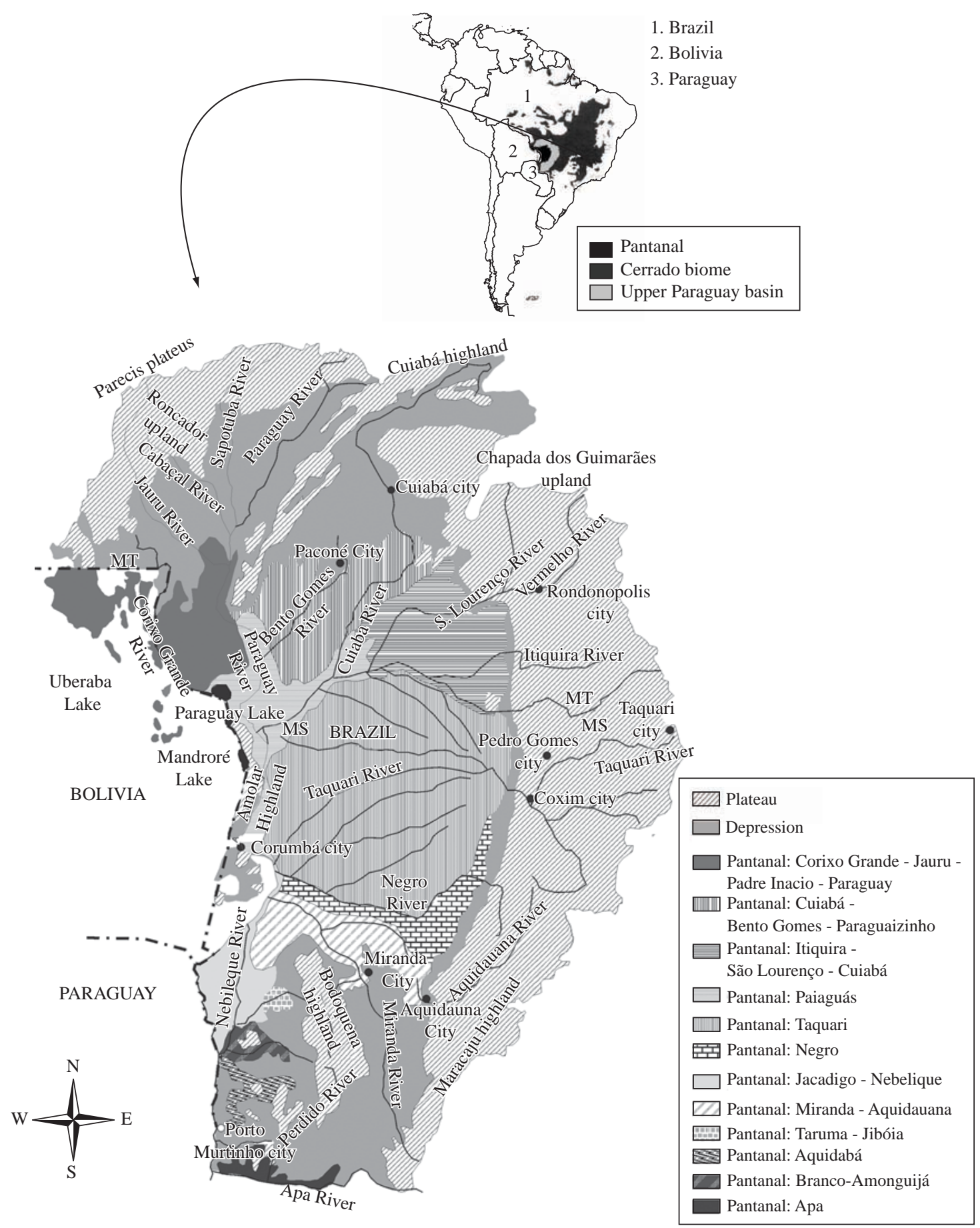

Figure 1. The Pantanal wetland and the surrounding upland (Planalto), in the center of South America, with its large portion in Brazil, and a small part entering Bolivia to the north and also touching Paraguay to the south. The tributaries of the upper Paraguay are slow moving when they meet the flatland and periodically overflow their banks. The Upper Paraguay River Basin encompasses the Pantanal, which is a complex mosaic of seasonally flooded wetland habitats with $147,574 \mathrm{~km}^{2}$, as a result of the ebb and flow of the flood waters, the topography and nutrient flows, providing feeding and reproductive niches for the biodiversity. The biodiversity of the Pantanal has the biogeographic influence of its neighboring biomes: the Cerrado to the east, the Amazonia to the north, and the Chaco to the south, in addition to some extension of the Atlantic Forest. Source: Alho, 2005. 
factors de ne the nature of each kind of wetlands and the vegetation it supports. Wetlands often represent a temporal and spatial transition from open water to dry land, and some plant species can bridge the transition between aquatic and terrestrial conditions.

Thus, the Pantanal is strongly affected by hydrology (wet and dry seasons) and so by nutrient enrichment that affects food-web and aquatic as well terrestrial communities. These trophic relationships include food resources, consumers, and potential competitors in ecological constraints on the occurrence and abundance of species in the biome. Species abundance in the Pantanal is a key factor related to seasonal offer of ecological resources, including feeding and reproductive niches. The region is well known as nursery and foraging habitats for a large number of species, some of them present in an enormous number of individuals, such as waterfowl, caimans, capybaras and many others. Reasons for the observed seasonal variability in food and reproductive niches supply include differences in nutrient enrichment and flooding regimen. It involves the biogeochemical cycling of nutrients as well as the production of phytoplankton, zooplankton, microfauna and macrophytes living in the aquatic system.

Contact of the river water with the floodplain results in depletion of dissolved oxygen $\left(\mathrm{O}_{2}\right)$, oversaturation of carbon dioxide $\left(\mathrm{CO}_{2}\right)$ and methane $\left(\mathrm{CH}_{4}\right)$, loss of suspended sediments, and reduced export of nitrogen $(\mathrm{N})$ and phosphorous $(\mathrm{P})$. Oxygen depletion and associated chemical changes are most marked when river water rst contacts the floodplain; in some years, the water remains anoxic throughout the river channel and ponds for some weeks, causing massive sh mortality. This phenomenon is locally known as "dequada". Most chemical weathering of minerals seems to take place in the upland drainage basins rather than on the floodplains, and most major solutes display conservative mixing in the river-floodplain system (Hamilton et al., 1997). The habitats change as a function of the water discharge carrying nutrients and sediments, depositing inorganic and organic matters that enrich the microhabitats, favoring the proliferation of microorganisms, invertebrates, shes, and so on.

Thus, three major factors characterize the Pantanal wetland: water, substrate and biota. The hydrological phenomenon is evident in the region. The substrate feature is a result of the geomorphologic and climatic evolutions, which support recurrent and sustained saturation. A representative biota arises from species of flora and fauna speci cally adapted to the local flooding cycles. So, indicators for the three factors (water, substrate and biota) can be easily identi ed (Alho, 2005).

\subsection{Influence of hydrologic pulses on vegetation: habitat heterogeneity}

The dry and wet cycle affects the dynamics, ecological succession of the biota such as aquatic plants and community composition and structure in ponds of the Pantanal (Pott et al., 1996). During the dry season
18 species were recorded and Pistia stratiotes L. had the highest absolute and relative frequency, followed by Salvinia auriculata (Micheli) Adans, Oxycaryum cubense Poepp and Kunth, Eichhornia azurea (Sw.) Kunth and Hydrocleys nymphoides (Humbold and Bonpland ex Willd.) Buchenau. During the wet season, with the enlarged pond ("baías), 38 species were found with highest absolute and relative frequencies of Oxycaryum cubense Poepp. and Kunth, Eichhornia azurea (Sw.) Kunth, Ludwigia sedoides (Humbold and Bonpland) Hara, Salvinia auriculata (Micheli) Adans, Utricularia gibba L., Hydrocleys nymphoides Humbold and Bonpland ex Willd.) Buchenau and Luziola subintegra (Sw.). A list of Pantanal plants, as a result of a 10 year period of eld work, offering information on identi cation, distribution and use reached 1,863 Phanerogams species (Pott and Pott, 1994)

In flooded areas of the sub-region of Paiaguás, the plant community in arboreal pockets of savanna ("capões de cerrado") changes, determining de ned landscape characteristics (Pott and Adamoli, 1996). In areas not or rarely flooded, there is predominance of the grass "capim-carona" Elyonurus muticus (Sprengel) Kuntze followed by the "lixeira" tree Curatella americana L. In forest pockets, under moderate flooding, there is a dominance of "cambará" Vochysia divergens Pohl, in many cases transforming the landscape into continuous and homogeneous forest locally named "cambarazal". In areas with a high degree of inundation, the "canjiqueira" Byrsonima orbygniana A. Juss. predominates, also forming homogeneous units called "canjiqueiral".

At the same time, well-adapted plants occupy the available spaces and, during the wet season, the aquatic species rapidly reproduce. The trees interact with the environment through their roots. The organic matter, dead or alive, is rapidly altered, favoring the proliferation of invertebrates and the migration of shes from the river to the flooded areas.

The higher ground (where there are patches of savanna and "cordilheira" of woodland) is only a couple of meters above average water level. The "cordilheiras" are the higher parts of ancient dunes presently covered with forested savanna or semi-deciduous forest. Along rivers the gallery forest is covered by vines such as "cipó-dearraia" Cissus spinosa Cambess. and "uvinha" Cissus sicyoides L. They are more or less vigorous depending on the flooding pattern.

The areas in the shadowed interior of the gallery forests produce less algae and biomass of floating plants than the sunny areas, but they receive more dead leaves, branches and dead trunks, which play a crucial role in the energetic balance of the system (Wantzen and Junk, 2000). Substrates of dead trees are generally sources of diversity and abundance for invertebrates.

During the high water level, the flow is slow through depressions locally known as "corixos" or shallow water paths, "vazantes". The depth of the water close to the 
river channels is less than six meters and near two meters on the floodplains.

Ecological processes such as the flooding regime, however, are not the exclusive factor affecting biodiversity. The seasonal change between the aquatic and terrestrial phases resulting in rapid nutrient cycling allows productivity for a region generally considered nutrient poor.

In conclusion, the annual rising and falling phases of the waters result in: a) influencing plant species richness, diversity and distribution patterns; b) adaptation to a wide range of flooding habitats; and c) decreasing local habitat diversity and maintenance of landscape diversity and heterogeneity.

One of the most important publications on the Pantanal is the PCBAP (Plano de Conservação da Bacia do Alto Paraguai $=$ Plan for Conservation of the Upper Paraguay Basin), describing the physical and biotic environments of the Pantanal (PCBAP, 1997). The PCBAP surveyed 3,400 species of superior plants occurring in the upper Paraguay River basin and half of this number is considered to occur in the Pantanal. The phytophysiognomic units of Pantanal are characterized by their phytosociological and ecological arrangements, forming well de ned landscape units going from inundated floating plants, seasonal flooding elds, gallery forests, scrub and semi-deciduous forests and different kinds of Cerrado savanna (Alho, 2005).

\subsection{Flooding and feeding effects on fish movement}

Out of its $147,574 \mathrm{~km}^{2}$ the Pantanal is estimated to have an average inundated area of $43,000 \mathrm{~km}^{2}$, which expands during the wet season. About 400 sh species are estimated to live in the region (plateaus and plains). Britiski et al. (1999) listed 263 species for the Pantanal. This list does not include species living in the upper river habitats.

Fish are an important resource, both ecologically and socially. Because of the great variety of feeding and reproductive niches for sh, the Pantanal harbors high species diversity and considerable abundance. Fishing is of fundamental social-economic importance for local people. In addition, shing for sport is one of the incentives to attract tourists to the region.

The most-captured commercial sh species are: "pintado" Pseudoplatystoma corruscans Spix and Agassiz, 1829, "cachara" Pseudoplatystoma fasciatum Linnaeus, 1766, "dourado" Salminus maxillosus Valenciennes, 1850, "pacu" Piaractus mesopotamicus Holmberg, 1887, "curimba" Prochilodus lineatus Valenciennes, 1836, "piranhas” Serrasalmus spilopleura Kner, 1858 and S. marginatus Valenciennes, 1837, "piavuçu" Leporinus macrocephalus Garavelo and Britski, 1988, "barbado" Pinirampus pinirampu Spix and Agassiz, 1829, "jaú” Paulicea luetkeni Ihering, 1898, "bagre" Pimelodus argenteus Perugia, 1891, "cabeçudo" P. ornatus Kner, 1858, "jurupuca" Hemisorubim platyrhynchos Valenciennes, 1840, “jurupensem"
Sorubim lima Bloch and Schneider, 1801, "pacu-peba" Mylossoma orbignyanum Valenciennes, 1849, and "piraputanga" Brycon microlepis Perugia, 1897. Fish farming is a growing activity in the region. The sh species composition may change from one wet season to another, depending on the pattern and duration of the inundation.

Three distinct phases can be distinguished in the sh cycle in relation to the water regime in the Pantanal (PRODEAGRO, 1997):

1. Flood season, a period of continuous rain with inundation of the plains, occurring from October to April. First, in the "piracema" type of migration the sh schools move upstream at the beginning of the rainy season. Later, migratory sh leave the riverbed and move into the adjacent flooding areas searching for food. Reproduction occurs at the beginning of the rainy season when a schooling behavior known as "rodada" is observed. Therefore, the "rodada" occurs at the end of the migratory trip known as "piracema";

2. Drainage season, a period coinciding with the end of the rainy season from April to May. Fish disperse from flooded areas to the riverbed and permanent ponds or lagoons. This sh movement is known as "lufada". During this period sh are pursued and caught by natural predators; and

3. Dry season, running from June to October. Fish start organizing schools for reproductive migration (piracema). Sedentary species face low levels of dissolved oxygen in the shallow water and some stay dormant in the mud during the dry season. Thus, the flooding cycle is determinant for migration and successful reproduction.

\subsection{Response of amphibians to the flooding regime}

Compared to other Brazilian biomes, the Pantanal presents a herpetofauna low in diversity but high in abundance. Among amphibians there are around 80 species occurring on the upper Paraguay Basin, 41 of which occur on the plains, (Alho et al., 2002; Alho, 2005; Sabino and Prado, 2006).

During the rainy season, the region presents vigorous populations of amphibians, thanks to the expansion of favorable habitats. About half of the anuran species in the Pantanal live in trees. Some species, such as the spottedtree-frog Hyla punctata Schneider, 1799, show association with permanent bodies of water (rivers and ponds) and others, such as the purple-barred-tree-frog Hyla raniceps Cope, 1862, the green-leaf-frog Scinax acuminatus Cope, 1862, the yellow-and-black-tree-frog Scinax fuscovarius Lutz, 1925, tolerate droughts but population suddenly grows when flooding comes, usually October to May. Frogs are also more vocal during this period. The tiny clicking-frog Lysapsus limellus Cope, 1862 lives on floating vegetation and vocalizes also by day. Others that vocalize on floating plants are the paradox-frog Pseudis paradoxa Linnaeus, 1758 and the speckled-bellied-frog Physalaemus albonotatus Steindachner, 1864. During the 
rainy season this Physalaemus albonotatus frog is one of the most conspicuous and vocal when they join in a sonorous choir, even by day.

Amphibians with terrestrial habits are the leaf-toad Bufo typhonius Linnaeus, 1758, the frogs Chiasmocleis mehelyi Caramaschi and Cruz, 1997, Leptodactylus elenae Heyer, 1978, Physalaemus cuvieri Fitzinger, 1826, and the arboreal frog Phrynohyas venulosa Laurenti, 1768. Another tiny frog living in dead tree holes in the forest is Chiasmocleis mehelyi Caramaschi and Cruz, 1997, which was only recently reported in the Pantanal. Some other species live at the water line between aquatic and terrestrial habitats, such as Pseudopaludicola aff. falcipes Hensel, 1867, Leptodactylus fuscus Heyer, 1978, Leptodactylus podicipinus Cope, 1862, Bufo paracnemis Lutz, 1925, Bufo granulosus Spix, 1824 and Elachistocleis cf. ovale Schneider, 1799. A colorful aposematic species is Phyllomedusa hypochondrialis Daudin, 1800.

\subsection{Response of reptiles to the flooding regime}

There are around 113 reptile species living in the Pantanal and 189 in the Cerrado biome (Alho et al., 2002; Alho, 2005; Sabino and Prado, 2006). There are more than 30 species of snakes. The yellow-anaconda Eunectes notaeus Cope, 1862 is very common on the plains and is small in size compared to the other species, and the green anaconda E. murinus Linnaeus, 1758 lives at the edge of the Pantanal and may reach $5 \mathrm{~m}$ in size. Another large snake is the water-queen Hydrodynastes gigas Duméril, Bibron and Duméril, 1854, which occurs at the borders of gallery forests or patches of savannas looking for toads, their preferred food. Small nocturnal snakes, which prey upon frogs, are Thamnodynastes cf. strigilis Thunberg, 1787, Leptodeira annulata Linnaeus, 1758 and Liophis poecilogyrus Wied-Neuwied, 1825.

The caiman Caiman crocodillus Linnaeus, 1758 is abundant and conspicuous, particularly during the dry season, being one of the symbols of the Pantanal. Twenty species of lizards are known for the region, all preferring dry habitats except for the Pantanal-caiman-lizard Dracaena paraguayensis Amaral, 1950, which lives in the water.

\subsection{Response of waterfowl to the flooding regime}

There are 463 bird species recorded only for the floodplains, 665 species when the uplands are included, and 837 species for the Cerrado biome (Alho et al., 2002; Alho, 2005; Sabino and Prado, 2006; Tubelis and Tomás, 2002; Silva, 1995). Bird species with aquatic habits are very common and abundant, including egrets such as species of the genera Casmerodius, Egretta, Ardea, Tigrisoma, Botaurus, in addition to the wood-stork Mycteria americana Linnaeus, 1758, the maguari-stork Ciconia maguari Gmelin, 1789 and the jabiru Jabiru mycteria Lichtenstein, 1819. King shers are present with 5 species of the two genera Ceryle and Choroceryle. Other aquatic species are the southern-screamer Chauna torquata Oken, 1816, the muscovy-duck Cairina moschata Linnaeus, 1758, the fulvous-whistling-duck Dendrocygna bicolor Vieillot, 1816, the white-facedwhistling-duck D. viduata Linnaeus, 1766, the blackbellied-whistling-duck D. autumnalis Linnaeus, 1758 and the Brazilian-duck Amazonetta brasilienses Gmelin, 1789. Among birds of prey are the snail-kite Rosthramus sociabilis Vieillot, 1817, the black-collared-hawk Busarellus nigricollis Latham, 1790, the great-blackhawk Butteogallus urubitinga Gmelin, 1788 and the Crane-hawk Geranospiza caerulescens Vieillot, 1817. Parrots are abundant.

Abundance is likely due to mobility, body size, ability to exploit the available seasonal resources, homeothermy, longevity, association with the water or generalist predator species. Waterfowl are exceptionally abundant and include 13 species of herons and egret (e.g. Casmerodius, Egretta and Pilherodius), three stork (Mycteria, Ciconia, and Jabiru), six ibis and spoonbill, and 5 species of king sher (Ceryle and Chloroceryle). Parrots are ubiquitous (19 species) and comprise 5 species of macaw, including Anodorhynchus hyacinthinus Latham, 1790. Rheas (Rhea americana Linnaeus, 1758) and crested seriemas (Cariama cristata Linnaeus, 1766) are common.

Most waterfowl species exhibit synchronized reproduction, where huge colonies of birds such as wood stork (Mycteria americana Linnaeus, 1758) egrets (snowy egret Egretta thula Molina, 1782, great white egret Casmerodius albus Linnaeus, 1758 and the capped heron Pilherodius pileatus Boddaert, 1783) and others such as the spoonbill Ajaia ajaja Linnaeus, 1758 concentrate in nesting sites in the gallery forest, during the dry season, to take advantage of the seasonal resources available. Breeding colonies are formed by hundreds of nesting birds following a pattern of species breeding at the same site or designated trees. There is a strong relation between nesting behavior exhibited by the bird species and seasonal variation of the water level. The birds take advantage of concentrations in ponds of shes and invertebrates. The concentration of birds in rookeries allows concentration of nutrients due to dropping feces, prey and hatchlings on the ground which, in turn, attracts predators such as caimans, anacondas, wild foxes and others.

Two waves of breeding species in the same reproduction trees are recognized: a white rookery and a black rookery. In the sub-region of Barão de Melgaço, during the dry season, in the period of July-October, the white rookery is established in a few selected trees of the Cuiabá River gallery forest, nearby ponds and flooded areas, with 600 nests concentrated in a single nesting site. This white rookery is composed rst by hatchlings of the wood-ibis Mycteria americana Linnaeus, 1758 , followed in lower proportions by hatchlings of the egrets Ardea alba Linnaeus, 1758 and Egretta thula Molina, 1782, and nally by hatchlings of the spoonbill $($ Platalea $=$ Ajaia ajaja Linnaeus, 1758). The black 
rookery is composed of the cormorant Phalacrocorax brasilianus Humboldt, 1805 = olivaceus, followed by the anhinga Anhinga anhinga Linnaeus, 1766 and the last species reproducing the white-necked heron Ardea cocoi Linnaeus, 1766.

There is a clear linkage between the flooding regimen of the Pantanal and the availability of food for the adult jabirus Jabiru mycteria Lichtenstein, 1819 to raise their young. The birds need low water, especially in ponds, in order to obtain the food they can catch with their specialized beak. The preferred food is "mussum" sh (Synbranchus marmoratus Bloch, 1795), which can stay dormant and encapsulated in the mud throughout the dry season, to swim again when the water arises in the rainy season. The jabiru is a specialist in detecting and catching the dormant sh in the muddy bed of the drying pond. They also catch snails (Pomacea spp). Jabirus migrate during the flooding season to higher grounds to still unknown sites.

\subsection{Seasonal flooding affecting mammal abundance and movement}

A total of 132 mammal species occur in the Pantanal while in the Cerrado there are 195 species. Capybaras (Hydrochaeris hydrochaeris Linnaeus, 1766) occur throughout the region (Alho et al., 2002; Alho, 2005; Sabino and Prado, 2006).

The coati Nasua nasua Linnaeus, 1766 is one of the most frequently observed species in the Pantanal (Alho et al., 1988b). They are opportunistic feeders eating crabs and other invertebrates such as bugs, termites and cicadas in grasslands near ponds during the dry season or feeding on fruits at arboreal habitats. The fox "lobinho" Cerdocyon thous Linnaeus, 1766 is also very frequently observed. They are omnivorous, eating fruits and preying on insects, amphibians, reptiles, birds and mammals. During the dry season, they prefer crustaceans such as crabs. The giant anteater Myrmecophaga tridactyla Linnaeus, 1758 is active during the day, in open areas, being a distinctive animal with its long tail and elongated snout. The giant anteater forages in open areas visiting termite mounds or ant nests where it nds insects by rooting with its nose or by digging with its powerful front claws. The other observed anteater species Tamandua tetradactyla Linnaeus, 1758 is of a smaller size. The tail is prehensile since this species has a more arboreal habit, also feeding on both termites and ants.

Howler monkey Alouatta caraya Humboldt, 1812 is observed in canopies of gallery forests and other forest habitats. These primates are vegetarian, feeding mainly on new sprouts of trees and so they depend upon the phenological rhythms of the forest which is influenced by flooding.

Highest abundance of mammal species is observed in the Pantanal during the dry season (August and September), when there is considerable expansion of terrestrial habitats, mainly seasonally flooded grassland (Mamede and Alho, 2006). Animal abundance (in terms of observed individual frequencies) vary during dry and wet seasons, being the seasonally flooded grassland the most utilized habitat by mammals in the dry season. In this study a total of 36 mammal species and 1,299 observations of individuals were recorded in the eld. The most frequently observed species were the capybara Hydrochaeris hydrochaeris Linnaeus, 1766, the marsh-deer Blastocerus dichotomus Illiger, 1815, the fox Cerdocyon thous Linnaeus, 1766 and the brocket Mazama gouazoubira G. Fisher, 1814. Thus, there is signi cant association of species utilization and kind of available seasonal habitat. The months with the greater number of observations of individuals were August and September, coinciding with the dry season, when more expansion of grassland elds (seasonally flooded) is observed.

Capybaras: Studies on capybaras show that the use of habitats varies seasonally (Alho et al., 1989). During the dry season, capybaras spend the night in the forest. In the early morning they leave the forest to graze on the grassland. During the rainy season, the capybaras also spend the night in the forest, but in the morning usually emerge and go directly to the water or to grazing areas. Use of aquatic and forest vegetation in their diet at that time increases signi cantly, since few grazing areas remain above water level.

Many aspects of the behavior and ecology of the capybara are affected by seasonal fluctuations in the amount of available food. Some preferred food items that are richer in protein tend to be more seasonal than poorer food items. There is a period of the year, from June until November, when the standing crop on lower areas susceptible to flooding is abundant and is consumed by capybaras. During the remainder of the year the presence of these food items is very scarce. Thus, the times of food abundance and scarcity are predicted by the flooding pattern. Capybara group size increases from the beginning (rainy season) to the middle of the year (dry season). During the floods the groups subdivide and are largely con ned to the forest patches, while in the dry season more animals are observed feeding on the pasture of the grassland.

Marsh deers: All vegetation communities in which marsh deer Blastocerus dichotomus Illiger, 1815 have been observed (Tomás, 1993) are frequently flooded during the wet season (most habitats are formed by aquatic plants). The vegetation type most used by marsh deer is Andropogon grassland and other open areas are dominated by Pontederia, Scleria, Nymphaea, Eleocharis, Thalia, Axonopus, Oryza, Nymphoides and Luziola communities. Marsh deer select about 35 plant species, mainly aquatic plants. Pontederia cordata L. (including both flowers and leaves), Thalia geniculata L. (mainly flowers), Nymphaea spp. L., Aeschynomene sensitiva Sw., A. fluminensis Vell. Conc., Discolobium pulchellum Benth, Reussia spp. Endl., Leersia hexandra Sw. and others are frequently eaten by marsh deer. Tomás (1993) provides a list of those plants. 
Small mammals: Microhabitat use among small mammals in the Pantanal shows that two oryzomyine rodents - Oligoryzomys fornesi - formerly Oryzomys fornesi Massoia, 1973 and O. subflavus Wagner, 1842 are more generalized in their use of microhabitats than are two echimyed species - Clyomys laticeps Thomas, 1909 and Trichomys apereoides Lund, 1839 - (Lacher and Alho, 1989). Oligoryzomys fornesi Massoia, 1973 is a broad habitat generalist at the "Nhecolândia" sub-region. Oryzomys subflavus Wagner, 1842 selects the "cerrado" microhabitat. Both Clyomys and Trichomys were restricted to their transition microhabitat. Although both species overlap in the same microhabitat, competition is avoided since Trichomys is scansorial while Clyomys is fossorial.

Bats: The habitat heterogeneity that is altered by seasonal flooding can influence bat distribution and abundance in the Pantanal. The most frequent bat family occurring in the region is phyllostomidae, followed by molossidae and the most captured species are Artibeus planirostris Spix, 1823, Noctilio albiventris Desmarest, 1818, Molossus molossus Pallas, 1766, Myotis nigricans Schinz, 1821 and Carollia perspicillata Linnaeus, 1758 (Boing, 2008; Pissini, 2008). While the occurrence of frugivore species in the Pantanal (such as Artibeus planirostris Spix, 1823) reflects the dependence of fruit plants, on the other hand the occurrence of rare species (such as Chiroderma doriae Thomas, 1891 which is a habitat specialist), may indicate the good conservation condition of the habitats in the region. Another habitat sensitive species is the phyllostomidae Chrotopterus auritus Peters, 1856, a carnivore species, a night predator and very sensitive to habitat degradation. The trophic structure of the bat community in the Pantanal is predominantly composed of insectivore and frugivore species and the productivity of insects and fruits is directly dependent on seasonal flooding.

\section{Conservation}

\subsection{Response of biodiversity to environmental degradation}

The Pantanal has been impacted by non sustainable practices of socio-economic development. The major economic activities are cattle ranching, shery, agriculture, mining and tourism. The urbanization of the areas surrounding the plains are causing water pollution by discharge of liquid and solid waste and dejects, as in the case of the Cuiabá river, which crosses the large city of Cuiabá, receiving non-treated sewage discharge.

Some major conservation problems of the Pantanal floodplain originate on the plateaus (Planalto). Many farms have been established in the highlands surrounding the Pantanal and much of the natural vegetation has been converted to soybean plantations or by other activities (Alho et al., 1988a; Alho, 2005; Alho and Gonçalves, 2005). Among these problems are: erosion, compacted soil, pollution, including environmental contaminants, alterations in the water level, damming of rivers, and deposition of sewage and solid waste.

Deforestation, expanding agriculture, illegal shing and hunting, unplanned tourism, and pollution by pesticides have caused a progressive deterioration of natural habitats. Because of the huge demand for soybean plantations, and presently the expansion of sugar-cane, on the upland plateaus surrounding the Pantanal (Planalto), the application of toxic agricultural chemicals is very common (Alho and Vieira, 1997).

A new road system has motivated landowners to subdivide their land into several small lots for "developments". This has resulted in altering natural habitats, killing wildlife on the roads, and encouraging illegal shing and hunting, while producing an abundance of trash, including plastic objects.

Deforestation: Studies concluded that $17 \%$ of the Pantanal has been deforested through the use of re (mainly Cerrado patches or "capões de cerrado") and $63 \%$ of the natural vegetation cover of the surrounding plateaus in the Planalto (savanna woodland and semi-deciduous forest). Ranchers set re to the vegetation during the dry season as a "management" technique to "clean" the vegetation not used by cattle. The re is initially started in the grassland but due to open areas, dry vegetation and wind, the res often spread to savannas, woodland and forest. The rate of environmental degradation has been $2.3 \%$ per year (Harris et al., 2005). If the present rate of degradation continues, the Pantanal natural habitats will be destroyed in about 45 years. This study points out that, until 2004, $44 \%$ of the region was impacted by environmental degradation due to non-sustainable human activities, mainly by means of natural habitat loss and alteration, affecting wildlife. Speci cally in the Pantanal, more than $25,000 \mathrm{~km}^{2}$ of natural vegetation cover has been disrupted, in the wetland territory of both the states of Mato Grosso do Sul and Mato Grosso.

Threatened species and protected areas - Threatened species are those of cially recognized as endangered, threatened or otherwise at risk, through criteria established by the Ministério do Meio Ambiente - MMA (Livro Vermelho da Fauna Brasileira Ameaçada de Extinção (MMA, 2008)) or by the international policy of the World Conservation Union (IUCN Red List). There are 17 species listed for the Pantanal as threatened in the following categories: vulnerable, in danger and critically in danger.

Many of cially threatened and endangered species can be observed roaming free in the Pantanal. Large mammals such as the jaguar (Panthera onca Linnaeus, 1758) the marsh deer (Blastocerus dichotomus Illiger, 1815), giant anteater (Myrmecophaga tridactyla Linnaeus, 1758), giant armadillo (Priodontes maximus Kerr, 1792), and manned wolf (Chrysocyon brachyurus Illiger, 1815), among others, are present in natural habitats. Other mammal species listed are: bush dog (Speothos venaticus Lund, 1842), wild cats such as ocelot (Leopardus pardalis Linnaeus, 1758), oncilla 
(L. tigrinus Schreber, 1775), margay (L.wiedii Schinz, 1821), wildcat (Oncifelis colocolo Molina, 1782), puma (Puma concolor Linnaeus, 1771). Among bird species, the following are listed and occur in the region: fasciated-tiger-heron (Tigrisoma fasciatum Such, 1825), chestnut-bellied-guan (Penelope ochrogaster Pelzeln, 1870), hyacinth-macaw (Anodorhynchus hyacinthinus Latham, 1790), sharp-tailed-tyrant (Culicivora caudacuta Vieillot, 1818), and great-billed-seed- nch (Oryzoborus maximiliani Cabanis, 1851).

The area is still far from the planned goal to have $10 \%$ of its territory protected. Two major protected federal areas are established: the Pantanal National Park, with 135,000 ha, and the Taiamã Reserve, with 11,200 ha. The others are private reserves, such as the Ecological Station of SESC, at the sub-region of Barão de Melgaço, and Acurizal, Penha and Dorochê in the vicinities of the National Park. Other protected areas are located in the uplands such as the Chapada dos Guimarães and the Serra da Bodoquena.

The Brazilian environmental legislation is considered up-to-date covering a broad range of issues, but the major problem is its actual enforcement.

Acknowledgements - This paper is the product of research conducted in the Pantanal over more than two decades. I gratefully acknowledge the invitation of Dr. José Galizia Tundisi (Instituto Internacional de Ecologia) to present this chapter on the biodiversity of the Pantanal. I thank my wife Celina Alho for her valuable and careful revision of the manuscript.

\section{References}

ALHO, CJR., CAMPOS, ZMS. and GONÇALVES, HC., 1989. Ecology, Social Behavior, and Management of the Capybara (Hydrochaeris hydrochaeris) in the Pantanal of Brazil. In REDFORD, KH. and EISENBERG, JF. (Eds.). Advances in Neotropical Mammalogy. Florida, Gainesville: Sandhill Crane Press. p. 163-194.

ALHO, CJR., LACHER-Jr, TE. and GONÇALVES, HC., 1988a. Environmental degradation in the Pantanal Ecosystem of Brazil. BioScience, vol. 38, no. 3, p. 164-171.

ALHO, CJR., LACHER-Jr. TE., CAMPOS, ZMS. and GONÇALVES, HC., 1988b. Mamíferos da Fazenda Nhumirim, Sub-Região de Nhecolândia, Pantanal do Mato Grosso do Sul: Levantamento Preliminar de Espécies. Rev. Brasil. Biol. $=$ Braz . J. Biol., vol. 48, no. 2, p. 213-225.

ALHO, CJR. and VIEIRA, LM., 1997. Fish and wildlife resources in the Pantanal wetlands of Brazil and potential disturbances from the release of environmental contaminants. Environ.Toxic. and Chemistry, vol 16, no. 1, p. 71-74.

ALHO, CJR., STRÜSSMANN, C. and VASCONCELLOS, LS., 2002. Indicadores da magnitude da diversidade e abundância de vertebrados silvestres do Pantanal num mosaico de hábitats sazonais. Corumbá: Centro de Pesquisa Agro-Pecuária da EMBRAPA. Published in digital media (CD - ROM).

ALHO, CJR., 2005. The Pantanal. In FRASER, LH. and KEDDY, PA. (Org.). The World's Largest Wetlands - Ecology and Conservation. New York, USA: Cambridge University Press, p. 203-271. ISBN 0-521-83404-X.
ALHO, CJR. and GONÇALVES, HC. 2005. Biodiversidade do Pantanal. Ecologia e Conservação. Campo Grande-MS: Editora UNIDERP, 142 p. ISBN: 858739294-8.

ANA - AGÊNCIA NACIONAL DE ÁGUAS. 2004. Strategic Action Program for the Integrated Management of the Pantanal and the Upper Paraguay River Basin. Brasília, DF: ANA/GEF/ PNUMA/OEA, 315 p. ISBN 859827604-9.

BOING, S., 2008. Requisitos de hábitats de morcegos no Pantanal sul mato-grossense e Cerrado do entorno. Campo Grande: UNIDERP. [Unpublished Master Dissertation under the advice of Dr. Cleber Alho]

BRITISKI, MA., SILIMON, KZ. and BALZAC, SL., 1999. Peixes do Pantanal. Manual de Identificação. Corumbá, MS: EMBRAPA-CPAP. $184 \mathrm{p}+$ ilust.

FRANCO, MSM. and PINHEIRO, R., 1982. Geomorfologia. In PROJETO RADAMBRASIL, Levantamento de Recursos Naturais. Rio de Janeiro and Corumbá: Brasil, Ministério das Minas e Energia. Departamento Nacional de Produção Mineral., p. $161-224$.

HAMILTON, SK., SIPPEL, SJ and MELACK, JM. 1995. Oxygen depletion and carbon dioxide and methane production in waters of the Pantanal wetland of Brazil. Biogeochemistry, vol. 30 , no. 2, p. 115-141.

HAMILTON, SK., SIPPEL, SJ., CALHEIROS, DF. and MELACK, JM., 1997. An anoxic event and other biogeochemical effects of the Pantanal wetland on the Paraguay River. Limnol. Oceanogr., vol. 42, no. 2, p. 257-272.

HARRIS, MB., ARCANGELO, C., PINTO, ECT., CAMARGO, G., RAMOS-NETO, MB. and SILVA, SM., 2005. Estimativas de perda da área natural da Bacia do Alto Paraguai e Pantanal Brasileiro. Campo Grande, MS: Relatório técnico não publicado. Conservação Internacional.

KEDDY, PA. and FRASER, LH., 2005. Introduction: big is beautiful. In FRASER, LH. and KEDDY, PA. (Eds.). The Word's Largest Wetlands. Ecology and Conservation. Cambridge, NY: Cambridge University Press. p. 1-10.

LACHER-Jr., TE. and ALHO, CJR., 1989. Microhabitat Use Among Small Mammals in the Brazilian Pantanal. J. Mamm., vol. 70, no. 2, p. 396-401.

MAMEDE, S. and ALHO, CJR., 2006. Response of wild mammals to seasonal shrinking-and-expansion of habitats due to flooding regime of the Pantanal, Brazil. Braz. J. Biol. $=$ Rev. Bras. Biol., vol. 66, no. 4, p. 29-41.

MMA - MINISTÉRIO DO MEIO AMBIENTE. 2008. Livro Vermelho da Fauna Brasileira Ameaçada de Extinção. 2 volumes. MACHADO, ABM., DRUMMOND, GM. and PAGLIA, AP. (Eds.). Brasília: Ministério do Meio Ambiente, Biodiversidade 19.

PCBAP - Plano de Conservação da Bacia do Alto Paraguai. 1997. 3 volumes, 7 t. illustr., maps. V. 1 - Metodologia do Plano de Conservação para a Bacia do Alto Paraguai. V. 2 Diagnóstico Ambiental da Bacia do Alto Paraguai; t. 1 - Meio Físico; t. 2 - Hidrossedimentologia; t.3 - Meio Biótico; t. 4 - Sócio-economia de Mato Grosso; t. 5 - Sócio-economia de Mato G rosso do Sul; t. 6 - Aspectos Jurídicos e Institucionais de Mato Grosso; t, 7 - Aspectos Jurídicos e Institucionais de Mato Grosso do Sul. V. 3 - Análise Integrada e Prognóstico da Bacia do Alto Paraguai. Brasília: Ministério do Meio Ambiente, Programa Nacional do Meio Ambiente. 
PISSINI, LFO., 2008. Diversidade de espécies e estrutura de comunidades de quirópteros do Pantanal da Nhecolândia, Mato Grosso do Sul. Campo Grande: UNIDERP. [Unpublished Master Dissertation].

POTT, A. and ADAMOLI, J., 1996. Unidades de vegetação do Pantanal dos Paiaguás. In Anais do II Simpósio sobre recursos naturais e sócio-econômicos do Pantanal. Corumbá, MS: CPAP-EMBRAPA e UFMS, p. 183-202.

POTT, A. and POTT, VJ., 1994. Plantas do Pantanal. Corumbá: EMBRAPA/CPAP. 320 p.

POTT, VJ., CERVI, AC., BUENO, NC. and POTT, A., 1996. Dinâmica da vegetação aquática de uma lagoa permanente da Fazenda Nhumirim, Pantanal da Nhecolândia, MS. In Anais do II Simpósio sobre recursos naturais e sócio-econômicos do Pantanal. Corumbá, MS: CPAP-EMBRAPA e UFMS. p. 227-235.

PRODEAGRO, 1997. Projeto de Desenvolvimento Agroambiental do Estado de Mato Grosso. Governo do Estado de Mato Grosso. Cuiabá: Meio Biótico. [Paper in digital format $\mathrm{CD}]$.

SABINO, J. and PRADO, PI., 2006. Síntese do Conhecimento da Diversidade Biológica de Vertebrados do Brasil. In
LEVINSOHN, T. (Org.). Avaliação do Estado do Conhecimento da Diversidade Brasileira. Brasília-DF: Ministério do Meio Ambiente, vol. II, p. 55-143.

SHAFER, CL., 1990. The Nature Reserves. Island Theory and Conservation Practice. Washington, DC: Smithsonian Institution Press, 189 p. ISBN 0874748054.

SILVA, JMC., 1995. Birds of the cerrado region, South America. Steenstrupia, vol. 21, no. 2, p. 69-92.

TOMÁS, W., 1993. Status and Ecology of a Marsh Deer (Blastocerus dichotomus) population in southern Pantanal, Brazil. Brasília: WWF-Brasil Unpublished Report.

TUBELIS, DP. and TOMÁS, WM. 2002. aracterização da avifauna da planicie do Pantanal. Indicadores da magnitude da diversidade e abundância de vertebrados silvestres do Pantanal num mosaico de hábitats sazonais. Corumbá, MS: EMBRAPA, Centro de Pesquisa Agro-Pecuária. (CD - ROM).

WANTZEN, KM. and JUNK, WJ. 2000. The importance of stream-wetland-systems for biodiversity: a tropical perspective. In GOPAL, B., JUNK, WJ. and DAVIS, JA. (Eds.). Biodiversity in wetlands: assessment, function and conservation. Leiden: Backhuys Bublishers, vol. 1, p. 11-34.Z 